\title{
PENGARUH FOULING PADA PERMUKAAN MEMBRAN SERAT NANO SELULOSA BAKTERIAL DENGAN NANOPARTIKEL Ag DAN TiO
}

\section{THE INFLUENCE OF FOULING ON SURFACES OF NANOFIBER BACTERIAL

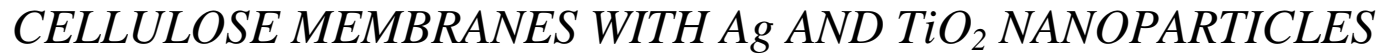

\author{
Suprihanto Notodarmodjo ${ }^{1}$, Srie Gustiani ${ }^{2}$, Cynthia $\operatorname{Radiman}^{3}$, Mindriani Syafila ${ }^{1}$ \\ ${ }^{1}$ Teknik Lingkungan, Fakultas Teknik Sipil dan Lingkungan, Institut Teknologi Bandung, \\ Jalan Ganesa 10,Bandung 40132, INDONESIA \\ ftsl@bdg.itb.ac.id \\ ${ }^{2}$ Balai Besar Tekstil, \\ Jalan Jend. A. Yani No. 390 Bandung, INDONESIA \\ E-mail: texirdti@bdg.centrin.net.id, sgustiani@yahoo.com \\ ${ }^{3}$ Kimia, Fakultas Matematika dan Ilmu Pengetahuan Alam, Institut Teknologi Bandung \\ Jalan Ganesa 10, Bandung 40132, INDONESIA
}

Tanggal diterima: 19 Juli 2016, direvisi: 25 Oktober 2016, disetujui terbit: 3 November 2016

\begin{abstract}
ABSTRAK
Nanopartikel Ag dan $\mathrm{TiO}_{2}$ terlekat pada permukaan serat nano selulosa bakterial (SB), dapat mencegah fouling pada membran yang disebabkan oleh pengolahan limbah berwarna. Pada penelitian ini telah dipelajari pengaruh nanopartikel $\mathrm{Ag}$ dan $\mathrm{TiO}_{2}$ terlekat pada permukaan serat nano selulosa bakterial terhadap fouling pada membran. Metode penelitian meliputi percobaan untuk memperoleh nilai fluks, resistensi, rejeksi, dan laju reaksi pada membran. Pada proses penelitian ini digunakan membran selulosa bakterial tanpa nanofotokatalis dan menggunakan nanofotokatalis dalam mengolah air limbah warna reactive black 5 (RB5), menggunakan reaktor membran fotokatalitik selulosa bakterial. Proses percobaan dilakukan skala laboratorium dengan sistem aliran crossflow, pH 11, konsentrasi warna limbah buatan $10 \mathrm{mg} / \mathrm{L}$, intensitas lampu UV 4,5 W/cm ${ }^{2}$ selama 120 menit, jumlah katalis $\mathrm{Ag}$ dan $\mathrm{TiO}_{2} 3,85 \mathrm{mg} / \mathrm{cm}^{2}$. Nilai laju pembentukan cake yang paling baik yaitu membran $\mathrm{SB} / \mathrm{Ag} / \mathrm{TiO}{ }_{2}$ sebesar $65 \mathrm{~L} / \mathrm{m}^{2}$.jam. Laju pembentukan cake yang diperoleh pada membran $\mathrm{SB} / \mathrm{Ag} / \mathrm{TiO}_{2}$ tidak mengalami peningkatan, hal tersebut dapat terjadi karena keberadaan $\mathrm{Ag}$ dan $\mathrm{TiO}_{2}$ yang menempel pada permukaan membran membantu mencegah terjadinya fouling melalui mekanisme degradasi fotokatalitik.
\end{abstract}

Kata kunci: nanopartikel, nanofiber, fotokatalitik, immobilisasi.

\begin{abstract}
Immobilization of $\mathrm{Ag}$ and $\mathrm{TiO}_{2}$ nanoparticles on the surface of bacterial cellulose (BC) nanofibers, was able to prevent fouling of the membrane caused by colored wastewater treatment. In this research, the influence of $\mathrm{Ag}$ and $\mathrm{TiO}_{2}$ nanoparticles immobilization on the surface of bacterial cellulose nanofibers to membrane fouling has been studied. Research methods include experiments to obtain the value of flux, resistance, rejection and membrane rate. In this research were used $B C$ membranes without and with nanocatalyst for treatment of wastewater reactive black 5 (RB5) dyed, using membrane photocatalyst reactor. Condition of experiment are laboratory scale reactor in operational crossflow system, $p H$ 11, dye concentration $10 \mathrm{mg} / \mathrm{L}$, UV lamp intensity $4.5 \mathrm{~W} / \mathrm{m}^{2}$ for 120 minutes and amount of $\mathrm{Ag}$ and $\mathrm{TiO}_{2}$ catalyst used were $3.85 \mathrm{mg} / \mathrm{cm}^{2}$. The optimum cake forming rate value was obtained of the membrane $\mathrm{SB} / \mathrm{Ag} / \mathrm{TiO} \mathrm{O}_{2}$ by $65 \mathrm{~L} / \mathrm{m}^{2}$.hr Cake foarming rate were obtained at $\mathrm{SB} / \mathrm{Ag} / \mathrm{TiO} \mathrm{O}_{2}$ membrane and doesn't increase, it can occur due to the existence of $\mathrm{Ag}$ and $\mathrm{TiO}_{2}$ which attached on the membrane surface helps prevent fouling through photocatalytic degradation.
\end{abstract}

Keywords: nanoparticles, nanofibers, photocatalyst, immobilization. 


\section{PENDAHULUAN}

Penelitian mengenai reaktor membran untuk memisahkan kontaminan dalam air limbah semakin berkembang, karena manfaatnya sangat menarik seperti kualitas efluen yang tinggi, mudah dikelola, ukuran yang kompak. Namun demikian proses membran masih memiliki kelemahan, yaitu terjadi fouling pada permukaan dan pori membran. Tantangan terberat dalam teknologi membran adalah terjadinya fouling. Adanya fouling dapat menyebabkan penurunan fluks. Fluks berbanding terbalik dengan selektifitas. Semakin tinggi fluks seringkali berakibat menurunnya selektifitas dan sebaliknya. Sedangkan hal yang diinginkan dalam proses berbasiskan membran adalah mempertinggi fluks dan selektifitas.

Fouling pada membran dapat disebabkan oleh material kimia seperti senyawa organik dan anorganik serta material biologi seperti mikroorganisme. Fouling menyebabkan fluks yang berpermiasi turun, sehingga diperlukan penggantian dan pencucian membran yang sering. Hal ini semua meningkatkan biaya operasional dan pemeliharaan ${ }^{(1)}$. Membran fouling mempunyai pengaruh terbesar pada ekonomi proses dan operasi instalasi filtrasi membran. Penelitian fouling yang ekstensif telah dipublikasikan, tetapi mekanisme fouling masih belum dapat dipahami dengan sempurna. Hal ini dikarenakan fouling merupakan fenomena yang sangat kompleks yang melibatkan banyak faktor. ${ }^{2}$ Studi terhadap terjadinya fouling pada permukaan membran telah dilakukan oleh beberapa peneliti. ${ }^{3}$ Untuk mencegah terjadinya fouling dapat dilakukan beberapa cara, diantaranya yaitu dengan cara menggunakan aliran crossflow pada proses membran, ${ }^{4}$ modifikasi pada permukaan membran ataupun modifikasi pada proses membran, ${ }^{\mathbf{5} 6}$ serta dapat pula dengan sistem backwash dan pencucian membran, proses preklorinasi, proses oksidasi ozon dan juga koagulasi sebelum filtrasi. ${ }^{7}$ Salah satu studi yang telah dipelajari adalah melakukan modifikasi terhadap proses membran, dengan menggunakan logam yang dilapiskan pada permukaan membran. ${ }^{8}$

Teknologi membran dipilih karena proses yang sederhana dan tidak menghasilkan limbah baru sehingga tergolong sebagai teknologi bersih. Salah satu kendala teknologi ini adalah harganya relatif mahal karena bahan baku untuk membuat membran masih harus diimpor. ${ }^{9}$ Pemanfaatan selulosa bakterial sebagai sumber selulosa pada pembuatan selulosa asetat merupakan salah satu alternatif untuk mendapatkan bahan baku pembuatan membran. Salah satu produk selulosa bakterial yang berasal dari fermentasi bakteri Acetobacter xylinum di dalam air kelapa dan telah dikenal oleh sebagian besar masyarakat sebagai produk makanan adalah nata de coco. ${ }^{10}$ Nata de coco berasal dari air kelapa, terdapat dalam jumlah yang melimpah di
Indonesia dan dapat digunakan sebagai sumber selulosa bakterial serta dapat dimanfaatkan sebagai bahan baku membran selulosa. Selulosa dan turunannya juga banyak digunakan sebagai bahan baku membran dalam proses mikrofiltrasi, ultrafiltrasi dan reverse osmosis. ${ }^{10}$ Selulosa bakterial ini mempunyai sifat kemurnian relatif tinggi dibandingkan selulosa kayu, antara lain bersifat sangat hidrofilik, sifat fisik mekanik yang tinggi dalam keadaan basah dan kering, berbentuk anyaman halus yang unik dan kuat serta diproduksi dari berbagai macam substrat yang relatif murah. Sifat mekanik yang baik dari produk fermentasi air kelapa ini memberi kemungkinan yang luas untuk dimanfaatkan lebih lanjut dalam bidang fisika dan polimer, disamping sebagai bahan makanan.

Penelitian mengenai polimer selulosa bakterial sebagai bahan baku membran, telah banyak dilakukan oleh Piluharto, (2009) yaitu membran berupa film tipis, baik membran mikrofiltrasi maupun ultrafiltrasi. Inovasi penggunaan nanopartikel $\mathrm{TiO}_{2}$ telah mendapatkan perhatian dalam meringankan fouling dan pengembangan reaktor membran fotokatalitik. $\mathrm{TiO}_{2}$ merupakan fotokatalis yang sangat baik, stabil terhadap panas dan mekanik. ${ }^{11}$ Menggabungkan nanopartikel $\mathrm{TiO}_{2}$ dengan membran dapat meningkatkan hidrophilisitas dan kinerja membran dalam menyisihkan foulants. Hal ini dapat pula meningkatkan porositas membran dan daya serap air pada membran. ${ }^{12,14}$ Selain itu perlekatan $\mathrm{TiO}_{2}$ pada permukaan membran dapat meningkatkan kinerja membran. Pada saat $\mathrm{TiO}_{2}$ disinari oleh sinar UV dengan panjang gelombang 10-400 nm, kemudian menyerap energi yang sama atau lebih besar dari energi band-gap, elektron dipromosikan dari pita valensi ke pita konduksi. Reaksi tersebut menghasilkan pasangan elektron hole yang bereaksi dengan oksigen atau molekul air terdekat untuk membentuk radikal $\mathrm{OH}$, yang dapat mengoksidasi berbagai zat. Membran dapat berfungsi dalam membunuh bakteri, mendegradasi kontaminan organik dan self cleaning setelah terkena paparan sinar matahari.

Modifikasi elektronik permukaan fotokatalis $\mathrm{TiO}_{2}$ melalui deposisi logam dengan menggunakan perak/Ag. Ag dipilih sebagai penjebak elektron karena tidak mudah teroksidasi dan memiliki potensial reduksi tinggi, sehingga $\mathrm{Ag}$ akan bertindak sebagai akseptor elektron. Oleh karena itu, nanopartikel $\mathrm{TiO}_{2}$ yang tersensitifkan Ag menunjukkan perubahan potensial negatif dan arus anoda dalam merespon penyinaran cahaya tampak, sehingga dapat meningkatkan laju proses fotokatalitik. ${ }^{14}$

Pada penelitian terdahulu yang dilakukan oleh Gustiani (2014), telah dipelajari mengenai karakterisasi membran selulosa yang diimobilisasi oleh nanofotokatalis $\mathrm{TiO}_{2}$ dan $\mathrm{Ag}$ sebagai katalis. $\mathrm{TiO}_{2}$ berfungsi sebagai fotokatalis dan Ag berfungsi 
sebagai katalis dalam proses fotokatalitik, sehingga dapat mempercepat proses fotokatalitik dan meningkatkan efisiensi penyisihan polutan organik dalam air dan air limbah.

Pada penelitian ini dibahas mengenai kemampuan $\mathrm{Ag}$ dan $\mathrm{TiO}_{2}$ sebagai fotokatalis dalam mencegah fouling pada permukaan membran yang disebabkan oleh warna pada air limbah tekstil. Membran yang digunakan hasil dari penelitian terdahulu yang dilakukan oleh Gustiani, 2014. Dari hasil penelitian terdahulu diperoleh membran yang diimobilisasi $\mathrm{Ag}$ dan $\mathrm{TiO}_{2}$, melalui metode pelapisan, dimana $\mathrm{Ag}$ dan $\mathrm{TiO}_{2}$ terikat pada permukaan membran melalui interaksi non kovalen. Membran selulosa bakterial direndam dalam berbagai konsentrasi suspensi $\mathrm{Ag}$ dan $\mathrm{TiO}_{2}$ untuk melihat pengaruh variasi konsentrasi terhadap penyisihan warna, pengurangan fouling dan sebagai antibakteri. Evaluasi terhadap pengurangan fouling dan aktivitas fotokatalitik dilakukan menggunakan larutan zat warna Reactive Black 5 (RB 5), masingmasing bertujuan untuk melihat kinerja membran.

\section{METODE}

\section{Bahan yang digunakan}

Bahan-bahan yang digunakan dalam penelitian ini meliputi membran serat nano SB terbuat dari nata de coco (sebagai tempat melekatnya nanofotokatalis $\mathrm{TiO}_{2}$ dan $\mathrm{Ag}$ ), $\mathrm{Ag}$ yang digunakan berupa nanopowder dengan ukuran partikel $<100 \mathrm{~nm}$ berbasis $99,5 \%$ trace metal diperoleh dari Sigma-Aldrich, $\mathrm{TiO}_{2}$ yang digunakan adalah titanium (IV) oxide nano powder $99,7 \%$ dengan ukuran rata-rata partikel $5 \mathrm{~nm}$ diperoleh dari SigmaAldrich, zat warna reactive black 5 diperoleh dari Dye Star untuk membuat limbah artifisial dan reagen. Zat kimia yang digunakan, meliputi reagenreagen untuk menganalisa air limbah hasil pengolahan.

\section{Alat yang digunakan}

Peralatan yang digunakan dalam penelitian ini meliputi peralatan gelas dan non gelas. Peralatan non gelas meliputi reaktor membran fotokatalitik terdiri dari support membran dan lampu UV-C 4,5 $\mathrm{W} / \mathrm{m}^{2}$ dengan panjang gelombang $365 \mathrm{~nm}$ untuk proses pengolahan air limbah warna, neraca analitik type SBA-31 (Denver instrument company AA200), hot plate (Heidolph MR 2002) untuk membuat air limbah buatan, spektrofotometer (Thermo Spectronic 20) Perkin Elmer untuk mengukur absorbansi larutan warna, lemari pendingin menyimpan limbah buatan, $\mathrm{pH}$ meter (pHep by HANNA).

\section{Membran yang digunakan}

Membran yang digunakan adalah membran selulosa bakterial yang diimobilisasi dan tidak diimobilisasi nanopartikel $\mathrm{Ag}$ dan $\mathrm{TiO}_{2}$, merupakan hasil dari penelitian sebelumnnya. ${ }^{\mathbf{8}}$ Membran serat nano yang digunakan adalah jenis flat sheet dari selulosa bakterial (nata de coco yang dikeringkan), dengan diameter $10 \mathrm{~cm}$. Serat nano digunakan sebagai tempat melekatnya nanopartikel $\mathrm{TiO}_{2}$ dan $\mathrm{Ag}$.

Membran $\mathrm{SB} / \mathrm{Ag} / \mathrm{TiO}{ }_{2}$ diperoleh melalui metode pelapisan, yaitu SB diimobilisasi oleh nanopartikel $\mathrm{Ag}$ dan $\mathrm{TiO}_{2}$. Beberapa variasi konsentrasi $\mathrm{Ag}$ dan $\mathrm{TiO}_{2}$ dibuat dengan cara melarutkannya pada $500 \mathrm{ml}$ aquadest, larutan kemudian dikocok menggunakan ultrasonic homogenizer selama 1 jam. Nata de coco yang digunakan adalah nata yang berumur 3 hari. Gel nata de coco kemudian direndam di dalam larutan $\mathrm{Ag}$ dan $\mathrm{TiO}_{2}$ selama 24 jam dan selanjutnya dikeringkan pada suhu ruangan sampai dengan kering ( \pm 7 hari). Metoda tersebut diperoleh hasil pengembangan percobaan di laboratorium.

Karakterisasi nanofiber yang dihasilkan dilakukan dengan mengamati beberapa parameter, diantaranya yaitu morfologi, fluks, rejeksi dan hambatan. Morfologi nanofiber dikarakterisasi dengan menggunakan Scanning Electron Microscope (SEM), alat yang digunakan adalah JEOL JSM6510/LV/A/LA.

\section{Reaktor membran fotokatalitik}

Reaktor didesain dalam skala laboratorium dengan dimensi $45 \mathrm{~cm} \times 40 \mathrm{~cm} \times 70 \mathrm{~cm}$, dengan support membran memiliki diameter $15 \mathrm{~cm}$. Support membran terbuat dari akrilat transparan dan besi. Lampu UV yang digunakan UV-C 4,5 W/m 2 , dengan panjang gelombang $365 \mathrm{~nm}$. Reaktor dilengkapi dengan pompa dan penampung berukuran $500 \mathrm{ml}$ dengan sistem aliran cross-flow.

\section{Proses pengolahan limbah cair warna buatan}

Penelitian mengenai membran fotokatalitik $\mathrm{SB} / \mathrm{Ag} / \mathrm{TiO}_{2}$ belum pernah digunakan oleh peneliti sebelumnya, karena merupakan hasil dari pengembangan di laboratorium. Membran fotokatalitik $\mathrm{SB} / \mathrm{Ag} / \mathrm{TiO}_{2}$ digunakan untuk dekolorisasi air limbah warna tekstil buatan yaitu zat warna RB5 dan juga mencegah fouling pada membran.

Konsentrasi zat warna RB5 yang digunakan yaitu $10 \mathrm{mg} / \mathrm{l}$. Percobaan degradasi zat warna dilakukan dengan variasi membran $\mathrm{SB}$ tanpa $\mathrm{Ag}$ dan $\mathrm{TiO}_{2}$, dengan $\mathrm{TiO}_{2}$ saja dan dengan $\mathrm{Ag}$ dan $\mathrm{TiO}_{2}$ dengan UV. Variasi penggunaan katalis yaitu nanofiber dilapisi oleh $\mathrm{Ag} 1,42 \mathrm{mg} / \mathrm{cm}^{2}$, nanofiber dilapisi $\mathrm{TiO}_{2} 3,21 \mathrm{mg} / \mathrm{cm}^{2}$ dan nanofiber dilapisi $\mathrm{Ag}$ dan $\mathrm{TiO}_{2} 3,85 \mathrm{mg} / \mathrm{cm}^{2}$. Proses membran fotokatalitik dilakukan selama 120 menit dengan 
sistem aliran crossflow, intensitas cahaya UV 4,5 $\mathrm{W} / \mathrm{m}^{2}$ serta tekanan 5 bar. Untuk melihat degradasi warna dilakukan pengambilan sampel tiap 15 menit kemudian dianalisa dengan menggunakan spektrofotometer pada panjang gelombang $610 \mathrm{~nm}$. Nilai absorbansi yang diperoleh, diplotkan terhadap kurva kalibrasi zat warna RB5.

Panjang gelombang optimum zat warna pada konsentrasi $10 \mathrm{mg} / \mathrm{L}$ diukur 3 kali di laboratorium pengujian lingkungan, Balai Besar Tekstil, Bandung. Panjang gelombang optimum zat warna RB5 dengan konsentrasi $10 \mathrm{mg} / \mathrm{L}$ adalah sebesar $610 \mathrm{~nm}$.

\section{Karakterisasi kinerja membran $\mathrm{SB} / \mathrm{Ag} / \mathrm{TiO}_{2}$}

Karakterisasi kinerja membran diperoleh dengan menghitung fluks dan efisiensi penyisihan warna pada limbah tekstil di Laboratorium Sarana Riset Kimia Tekstil, Balai Besar Tekstil, Bandung menggunakan Standard Methods for Examination of Water and Wastewater, 2003.

Mekanisme fouling bertujuan untuk melihat perubahan hambatan membran yang terjadi pada saat percobaan. Prosedur untuk melakukan studi tentang mekanisme fouling dilakukan dengan rincian sebagai berikut :

a) Rm didapat melalui pengukuran fluks air murni

b) Rt dihitung dari fluks akhir (yang stabil) hasil tempuhan untuk setiap variasi percobaan menggunakan persamaan (1).

$R_{t}=R_{m}+R_{f}+\mathrm{R}_{c}$

Setelah melakukan tempuhan, permukaan membran dibilas dengan air untuk menghilangkan lapisan cake. Kemudian dilakukan pengukuran fluks air murni untuk memperoleh $\mathrm{Rm}+\mathrm{Rf}$

c) Tahanan cake dihitung dari persamaan (2) $R c=R t-(R m+R f)$.

d) Tahanan fouling dapat dihitung dari persamaan (3)

$R f=(R m+R t)-R m$.

e) Laju reaksi degradasi warna yang terjadi pada proses membran fotokatalitik zat warna merupakan salah satu parameter evaluasi terhadap performa proses membran fotokatalitik. Persamaan kinetika terlebih dahulu harus ditetapkan untuk mendapatkan kinetika laju reaksi yang sesuai. Pada penelitian ini dilakukan percobaan pada reaktor membran fotokatalitik aliran crossflow dengan volume permeat $200 \mathrm{~mL}$ dengan interval waktu pengamatan 0-120 menit. Pengamatan perubahan konsentrasi zat warna dilakukan dengan mengukur perubahan absorbansi warna yang diukur menggunakan spektrofotometer kemudian diplotkan pada kurva kalibrasi absorbansi-konsentrasi. Pengukuran absorbansi warna air limbah mengandung RB5 dengan variasi konsentrasi zat warna dilakukan pada $\lambda_{\text {maks }} 610 \mathrm{~nm}$.
Kinetika degradasi warna dianalisa dengan data konsentrasi awal dan akhir degradasi zat warna RB5, menggunakan model persamaan BohartAdam seperti ditunjukkan pada persamaan (4). ${ }^{\mathbf{1 6}}$

$$
\ln \left(\frac{C o}{C t}-1\right)=k a_{o} \frac{z}{v}-k \operatorname{Cot}
$$

\section{HASIL DAN PEMBAHASAN}

Pada tulisan ini hanya disajikan data mengenai antifouling pada permukaan membran dalam mengolah air limbah warna reactive black 5 . Permasalahan mengenai fouling tidak dapat dihindari dan hal tersebut merupakan tantangan terberat dalam teknologi membran. Lapisan foulant yang terbentuk pada permukaan membran, dapat menghambat proses filtrasi, mengurangi efektivitas dan fluks membran. Hasil penelitian menunjukkan bahwa Ag dan $\mathrm{TiO}_{2}$ yang dilapiskan pada permukaan membran memberikan pengaruh terhadap pembentukan lapisan foulant pada permukaan membran.

Gambar 1 menggambarkan morfologi permukaan membran $\mathrm{SB} / \mathrm{Ag} / \mathrm{TiO}_{2}$ (a) setelah digunakan pada perbesaran $10000 x$ dan (b) setelah digunakan pada perbesaran 10000x. Gambar 1 menunjukkan bahwa membran $\mathrm{SB} / \mathrm{Ag} / \mathrm{TiO}_{2}$ sebelum dan sesudah digunakan terlihat tidak ada perubahan pada area permukaan. Pada permukaan membran yang telah digunakan tidak tidak tampak adanya polarisasi foulants. Hal tersebut dapat terjadi akibat dari pengaruh $\mathrm{Ag}$ dan $\mathrm{TiO}_{2}$ yang dilapiskan pada permukaan membran. Fotokatalis dapat menghilangkan foulants pada permukaan membran secara kuat. ${ }^{15}$

Pada Gambar 1 terlihat bahwa sebagian pori membran tersumbat oleh keberadaan fotokatalis $\mathrm{TiO}_{2}$. Penyumbatan pori membran dapat terjadi disebabkan oleh partikel fotokatalis itu sendiri. Rahimpour dkk, mengamati bahwa fluks air murni dari membran menurun dengan meningkatnya jumlah deposisi $\mathrm{TiO}_{2}$ dan penyumbatan pori oleh foulant.

Gambar 2 menunjukkan fluks membran SB tanpa $\mathrm{TiO}_{2}$ dan Ag, membran SB dengan Ag, dengan $\mathrm{TiO}_{2}$ dan dengan $\mathrm{TiO}_{2}$ dan Ag. Umumnya, membran dengan $\mathrm{TiO}_{2}$ menunjukkan perbaikan kinerja. Namun fluks tidak selalu mengambarkan hidrofilisitas dari membran. Gambar 2 menunjukkan fluks akhir membran tanpa $\mathrm{TiO}_{2}$ dan Ag, membran dengan Ag, membran dengan $\mathrm{TiO}_{2}$ dan membran dengan $\mathrm{TiO}_{2}$ dan Ag masing-masing setelah 120 menit sebesar 27, 24, 65 dan 50 $\mathrm{L} / \mathrm{m}^{2}$.jam. Membran tanpa $\mathrm{TiO}_{2}$ dan Ag serta membran dengan Ag pada awalnya memiliki nilai fluks yang lebih besar dibanding membran yang diberi fotokatalis $\mathrm{TiO}_{2}$ sebesar $100 \mathrm{~L} / \mathrm{m}^{2}$.jam, namun setalah 10 menit nilai fluks menjadi jauh 
berkurang hingga 120 menit. Hal tersebut terjadi disebabkan oleh terjadinya polarisasi foulant pada permukaan membran, sehingga pori membran tersumbat dan fluks air bersih dan air limbah warna menjadi mengecil.

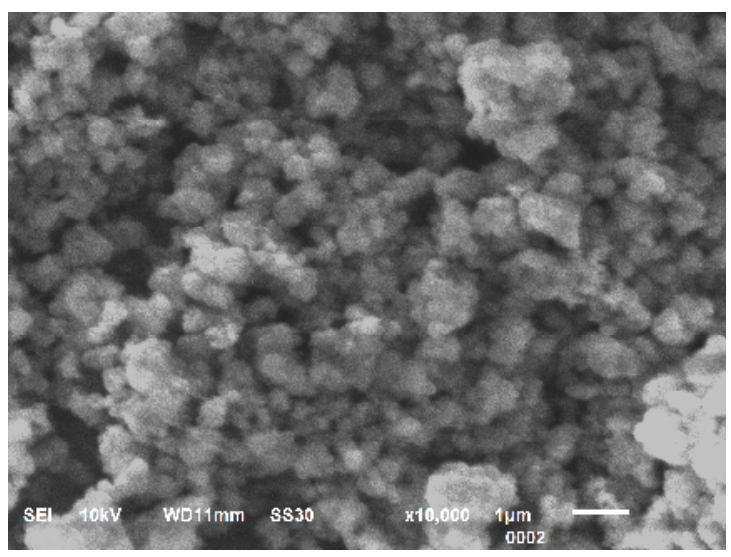

(a)

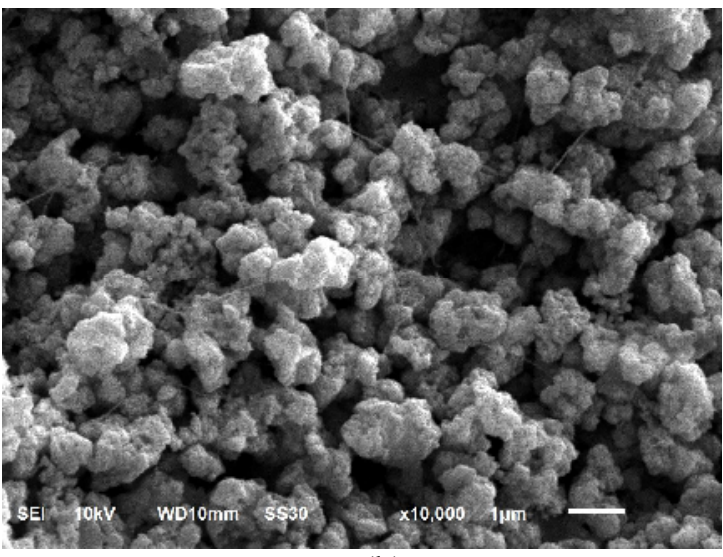

(b)

Gambar 1. Morfologi membran SB dilapisi $\mathrm{TiO}_{2}$ dan $\mathrm{Ag}$

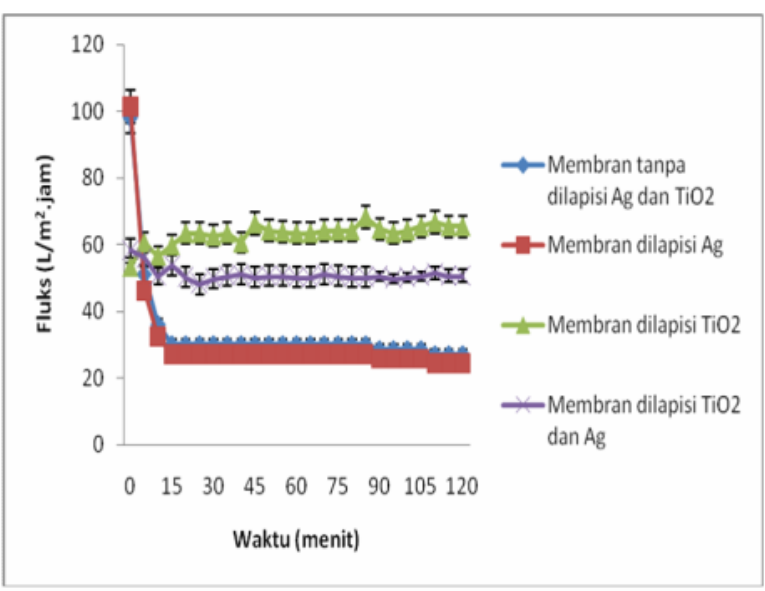

Gambar 2. Fluks membran SB
Keberadaan $\mathrm{TiO}_{2}$ terbukti dapat membuat fluks membran lebih stabil, terbukti dari nilai fluks membran $\mathrm{TiO}_{2}$ dan membran $\mathrm{Ag}$ dan $\mathrm{TiO}_{2}$ relatif lebih stabil selama waktu proses. Namun, dari awal proses nilai fluks jauh lebih kecil dibanding membran tanpa fotokatalis dan membran dengan $\mathrm{Ag}$, hal tersebut terjadi karena fotokatalis dapat pula menyebabkan penyumbatan pada pori membran. Diamater pori yang mengecil dapat memperkecil nilai fluks, sehingga kinerja membran menjadi menurun.

Penyumbatan pori lebih besar terjadi pada membran dengan $\mathrm{TiO}_{2}$ dan $\mathrm{Ag}$ dibandingkan pada membran $\mathrm{TiO}_{2}$. Hal tersebut ditunjukkan pada Gambar 2, penggunaan fotokatalis $\mathrm{TiO}_{2}$ dan $\mathrm{Ag}$ lebih besar dibanding $\mathrm{TiO}_{2}$. Penggunaan fotokatalis dalam jumlah yang lebih banyak dapat menyebabkan penyumbatan yang lebih besar, sehingga diperlukan jumlah muatan $\mathrm{TiO}_{2}$ yang optimal untuk meningkatkan hidrofilisitas pada permukaan membran tanpa pengaruh yang negatif pada ukuran pori.

Selain disebabkan oleh fotokatalis, penyumbatan pori disebabkan oleh foulant. Pada membran dengan $\mathrm{TiO}_{2}$ dan $\mathrm{Ag}$, fouling hanya disebabkan oleh keberadaan fotokatalis. Gambar 3 menunjukkan berbagai resistensi membran SB tanpa $\mathrm{TiO}_{2}$ dan Ag, membran dengan Ag, membran dengan $\mathrm{TiO}_{2}$ dan membran dengan $\mathrm{TiO}_{2}$ dan Ag. Membran tanpa $\mathrm{TiO}_{2}$ dan Ag memiliki resistensi cake ( $\mathrm{Rc}$ ) lebih tinggi dibandingkan membran lainnya. Meskipun membran ini bersifat hidrofilik, namun karena pori membran yang sedemikian rapat, sehingga mendorong terbentuknya lapisan cake pada permukaan membran (polarisasi foulant).

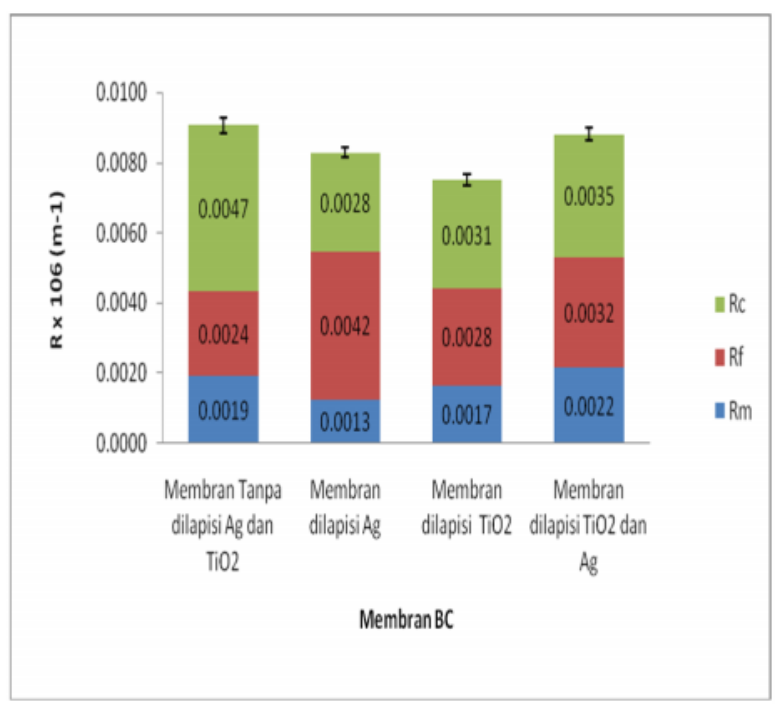

Gambar 3. Hambatan membran SB dalam mendekolorisasi limbah warna reactive black 5 dengan aliran crossflow. 
Fenomena yang terjadi pada membran dengan dengan $\mathrm{TiO}_{2}$ dan $\mathrm{Ag}$ yaitu penyumbatan pada pori yang disebabkan oleh penumpukkan fotokatalis pada permukaan membran. Hal tersebut dapat dilihat pada penampakan morfologi membran yang ditunjukkan pada Gambar 1. Hal lain yang dapat membuktikan bahwa penyumbatan pada permukaan membran $\mathrm{TiO}_{2}$ dan $\mathrm{Ag}$, dapat dilihat pada Gambar 4. Gambar 4 menyatakan bahwa membran $\mathrm{TiO}_{2}$ dan $\mathrm{Ag}$ dapat menghilangkan foulant lebih baik dari membran lainnya. membran $\mathrm{TiO}_{2}$ dan $\mathrm{Ag}$ dapat mendegradasi warna hingga 99,74\%. Keberadaan $\mathrm{TiO}_{2}$ yang diiradiasi sinar UV mampu memecah molekul air menghasilkan radikal hidroksida $\left(\mathrm{OH}^{\circ}\right)$ dan radikal $\mathrm{H}$. Radikal hidroksida menjadi zat pendegradasi yang akan menyerang berbagai gugus fungsi dalam larutan limbah buatan warna tekstil sehingga dapat dilakukan secara maksimal.

Membran $\mathrm{TiO}_{2}$ yang ditambahkan Ag pada permukaannya dapat meningkatkan reaksi fotokatalitik. Mekanisme migrasi elektron pada permukaan fotokatalis $\mathrm{TiO}_{2}$ yang termodifikasi logam Ag melalui tahap eksitasi elektron dari pita valensi ke pita konduksi dan setelah mengalami eksitasi, elektron bermigrasi menuju logam dan terperangkap dalam logam, sehingga rekombinasi electron-hole dapat ditekan, dan hole leluasa berdifusi ke permukaan fotokatalis di mana pada permukaan tersebut akan terjadi oksidasi senyawa-senyawa yang didegradasi.

Logam memiliki aktivitas katalitik dan memodifikasi sifak fotokatalitik fotokatalis melalui perubahan distribusi elektron. ${ }^{14}$ Sehingga adanya sumber foton yang mengaktivasi $\mathrm{TiO}_{2}$ yang tersensitifkan Ag, dapat mengurangi terjadinya hambatan pada permukaan membran.

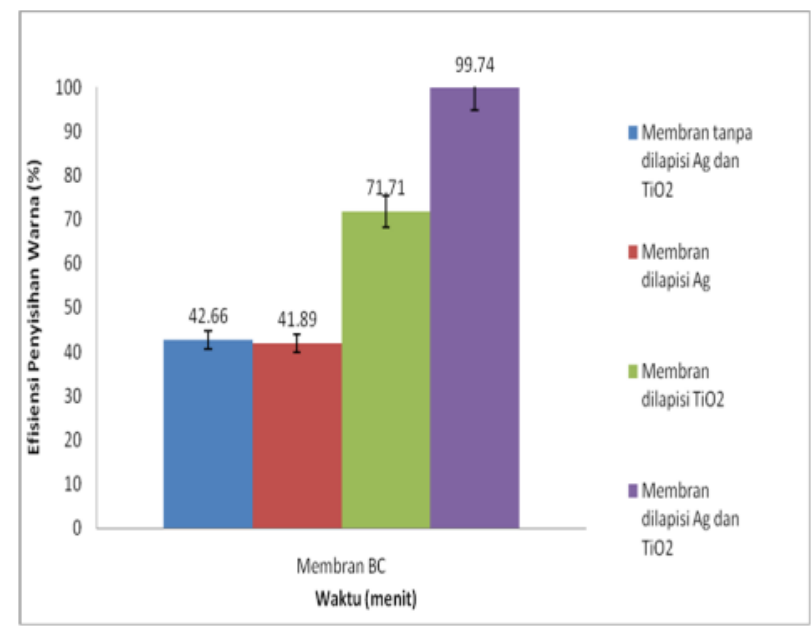

Gambar 4. Dekolorisasi limbah warna reactive black 5 menggunakan membran SB dengan aliran crossflow

Tabel 1 menjelaskan laju reaksi fotokatalitik dan pada membran SB tanpa $\mathrm{TiO}_{2}$ dan $\mathrm{Ag}$, membran dengan $\mathrm{Ag}$, membran dengan $\mathrm{TiO}_{2}$ dan membran dengan $\mathrm{TiO}_{2}$ dan Ag. Membran dengan $\mathrm{TiO}_{2}$ dan $\mathrm{Ag}$ memiliki laju reaksi lebih cepat dibandingkan dengan membran lainnya. Keberadaan $\mathrm{TiO}_{2}$ yang tersensitifkan $\mathrm{Ag}$ dapat mempercepat dan meningkatkan laju reaksi fotokatalitik dalam mendegradasi air limbah warna yaitu $202,71 \times 10^{-5} \mathrm{~mL} / \mathrm{mg}$ menit dibandingkan dengan membran $\mathrm{TiO}_{2}$ saja yaitu $152,49 \times 10^{-5}$ $\mathrm{mL} / \mathrm{mg}$ menit. Kecepatan reaksi dan efisiensi penyisihan warna yang lebih tinggi yang berarti bahwa degradasi terjadi lebih cepat dibandingkan membran dengan fotokatalis. Fouling yang diakibatkan oleh foulant berupa zat warna dapat dicegah pada membran dengan reaksi fotokatalitik.

Fouling akibat zat warna terjadi pada membran tanpa fotokatalis dan Ag saja, karena foulant degradasi zat warna yang terjadi lebih lambat dibandingkan dengan membran dengan fotokatalis (Tabel 1).

Tabel 1. Konstanta laju reaksi

\begin{tabular}{lcc}
\hline \multicolumn{1}{c}{ Membran } & $\begin{array}{c}\boldsymbol{k}^{\prime}(\mathbf{m L} \mathbf{m g} \mathbf{m e}- \\
\mathbf{n i t})\end{array}$ & Keterangan \\
\hline $\begin{array}{l}\text { Tanpa dilapisi } \mathrm{Ag} \\
\text { dan } \mathrm{TiO}_{2}\end{array}$ & $15,99 \times 10^{-5}$ & $\begin{array}{c}\text { Lebih } \\
\text { lambat }\end{array}$ \\
$\begin{array}{l}\text { Dilapisi dengan } \\
\mathrm{Ag}\end{array}$ & $31,06 \times 10^{-5}$ & Lambat \\
$\begin{array}{l}\text { Dilapisi dengan } \\
\mathrm{TiO}_{2}\end{array}$ & $152,49 \times 10^{-5}$ & Cepat \\
$\begin{array}{l}\text { Dilapisi dengan } \\
\text { Ag dan } \mathrm{TiO}_{2}\end{array}$ & $202,71 \times 10^{-5}$ & Lebih cepat \\
\hline
\end{tabular}

\section{KESIMPULAN}

Fouling pada membran yang disebabkan oleh foulant berupa zat warna dapat dicegah dengan menggunakan fotokatalis $\mathrm{TiO}_{2}$ pada permukaan membran. Keberadaan logam Ag dapat meningkatkan kinerja membran. Jumlah optimal fotokatalis yang menempel pada permukaan membran sangat menentukan kinerja membran. Fotokatalis yang menempel pada permukaan membran menyebabkan terjadinya penyumbatan pori-pori membran. Metode pembuatan membran dengan metode pelapisan mungkin kurang efektif, karena $\mathrm{TiO}_{2}$ yang menempel pada permukaan membran masih menyebabkan terjadinya fouling. Penelitian pembanding diperlukan lebih lanjut untuk dapat lebih mengetahui permasalahan ini.

\section{UCAPAN TERIMA KASIH}

Penulis mengucapkan terima kasih kepada Institut Teknologi Bandung (ITB) yang telah mendanai penelitian ini melalui Program Riset dan 
Inovasi Kelompok Keahlian 2012 serta Balai Besar Tekstil atas sarana penelitian yang telah digunakan.

\section{PUSTAKA}

${ }^{1}$ Chang, I.S., M. Gander, B. Jefferson dan S.J. Judd. (2001). Low-Cost Membrans for Use in a Submerged MBR. Trans I ChemE, 79 B: $183-188$.

${ }^{2}$ Liu, C. (2003). Membran Fouling: A Physicochemical Perspective, Conference proceedings, WEFTEC. Los Angeles, CA.

${ }^{3}$ Hai, I.F., Yamamoto, K. dan Fukushi, K. (2005). Different Fouling Modes of Submerged Hollow Fiber and Flat Sheet Membrans Induced by High Strength Wastewater With Concurrent Biofouling. Desalination, 180: 89-97.

${ }^{4}$ Puspayana. (2013). Pengolahan limbah cair tahu menggunakan membran nanofiltrasi silica aliran cross flow untuk menurunkan kadar nitrat dan ammonium. Jurnal Teknil ITS, 2, 2: 87-91.

${ }^{5}$ Buchori, L., Susanto, H. dan Budiyono. (2010). Sintesis Membran Ultrafiltrasi Non Fouling Untuk Aplikasi Pemrosesan Bahan Pangan. Reaktor, 13, 1:10-15.

${ }^{6}$ Ahmad, S. (2009). Peningkatan Fluks Membran Dengan Cara Perendaman Dalam Larutan Natrium Hipoklorit. Teknologi Indonesia, 32, 1: 31-36.

${ }^{7}$ Sulistyani, E. dan Fitrianingtyas, M. (2009). Pengendalian fouling membran ultrafiltrasi dengan sistem automatic backwash dan pencucian membran., Jurusan Teknik Kimia, Fakultas Teknik, UNDIP.

${ }^{8}$ Gustiani, S. (2014). Pengolahan efluen IPAL industri tekstil menggunakan membran nanofiber selulosa bakterial dengan nanopartikel Ag dan $\mathrm{TiO}_{2}$, Disertasi S3, Institut Teknologi Bandung Lindu, M., Puspitasari, T. dan Ismi, E. (2010). Sintesis dan Karakterisasi Selulosa Asetat dari nata de coco sebagai Bahan Baku Membran Ultrafiltrasi. Jurnal Sains Materi Indonesia, 12, 1: 17-23.

${ }^{9}$ Piluharto, B. (2009). Kajian Sifat Fisik Film Tipis Nata de coco sebagai Membran Ultrafiltrasi, Universitas Jember.

${ }^{10}$ M.N. Chong, B. Jin, C.W.K. dan Chow, C. (2010) Saint, Recent developments in photocatalytic water treatment technology: a review, Water Res. 44 : 2997-3027.

${ }^{10}$ Sulistyani, E. dan Fitraningtyas, M. (2010). Pengendalian fouling membran ultrafiltrasi dengan sistem automatic backwash dan pencucian membran, Artikel Teknik Kimia, UNDIP. 1- 4

${ }^{11}$ T.H. Bae dan T.M. Tak. (2005). Effect of $\mathrm{TiO}_{2}$ nanoparticles on fouling mitigation of ultrafiltration membranes for activated sludge filtration, J. Membr. Sci. 249:1-8.

${ }^{12}$ M.L. Luo, J.Q. Zhao, W. Tang, dan C.S. Pu. (2005). Hydrophilic modification of poly(ether sulfone) ultrafiltration membrane surface by self-assembly of $\mathrm{TiO}_{2}$ nanoparticles, Appl. Surf. Sci. 249 : 76-84.

${ }^{13}$ Y. Yang, H. Zhang, P. Wang, Q. Zheng, dan J. Li. (2007). The influence of nano-sized $\mathrm{TiO}_{2}$ fillers on the morphologies and properties of PSF UF membrane, J. Membr. Sci.288 : 231-238.

${ }^{14}$ Susanti. (2012). Preparasi nanopartikel $\mathrm{TiO}_{2}-$ anatas tersensitifkan perak $\left(\mathrm{TiO}_{2} @ \mathrm{Ag}\right)$ untuk fotodegradasi metilen biru, MSc Thesis, Universitas Negeri Yogyakarta.

${ }^{15}$ You, S. J., Semblante, G. U., Lu, S. C., Damodar, R. A. dan Wei, T. C. ( 2012). Evaluationof the Antifouling and Photocatalytic Ptoperties of Poly(vinylidene fluoride) Plasma-grafted poly(acrylic acic) Membran With Selfassembled $\mathrm{TiO}_{2}$, J Hazard Mater. 237-238: $10-9$. 
Arena Tekstil Vol. 31 No. 1 2016: 35-42 